\title{
STUDENTS' PERCEPTION ON THE USE OF COOPERATIVE LEARNING IN EFL LEARNERS
}

\author{
Dawi Yanti \\ STT-Migas Balikpapan \\ Email:wieaurora@gmail.com
}

\begin{abstract}
Studies repeatedly show that students' perceptions are an important determinant of students' behaviour and understanding of these perceptions help teachers to set a proper classroom environment for the students' need and characteristics. Therefore, this case study was conducted to observe the perception of 24 learners in Teknik Instrumentasi Electronika Migas at STT-Migas Balikpapan on the use of cooperative learning if it was able to improve the students' motivation, participation, academic achievement, and their positive respons toward learning.) The instruments used were a questionnaire. A survey questionnaire was distributed among the participants in order to determine their perception about employing cooperative learning. The result showed that cooperative enhances good working relationship among students mostly agreed by EFL learners $(87,5 \%)$, and then it was (70\%) learners agreed by cooperative learning help to socialize more and the last which percentage of $(66,6 \%)$ they agreed with cooperative learning enhances class participation. In conclusion, participant generally learning experiences contribute to social skills growth, where positive interpersonal and social relationship became to noticeable and more diverse. Through cooperative learning, individual and group work skills development enhances students' achievement.
\end{abstract}

Keywords: students perception, cooperative learning

\section{INTRODUCTION}

Students' learning individually is one of traditional education method and emphasizes the reciprocal result between students and teacher as well as students and book. However, as the development of education method from time to time changes continuously, modern method is now 
infrequently using the traditional method. One of the learning models that get a lot of response is cooperative learning (Hidayati et al. 2018). Cooperative learning or group work activity helps students obtain more information than work individually. It is able to increase their communication skill because they will always make contact with their group members and each other in the classroom.

Cohen and Lotan (2014) stated that cooperative learning can help students develop skills in communication. Cooperative learning is the opportunity for groups to work together and for students to talk to one another. This method creates a positive learning environment for students and allows students to have more opportunities for communication. Moreover, Cooperative learning has been proved to be an effective teaching strategy to both the teacher and learner. It encourages learning to take place and allow communication skills to foster among learners (Jacobs and McCafferty, 2006)

Cooperative learning or group work activity is good approach to apply in EFL learners. It makes students cooperate with their friends, interaction and solve the problem together. (Hidayati et al.2018). Li and Lam 2013 in (Miller, 2017) stated that cooperative learning is teacher's strategy for the students work in groups to achieve the goal. Applying cooperative learning as an education method it can positively impact academic achievement because makes students more active, selfesteem, social skills and also confidence. Daniels 2005 (Al-yaseen, 2014) also states that cooperative learning structures give students a framework of support for their language knowledge and from this framework. Students will provide their confidence in their language skills. Therefore, they will be comfortable in their learning environment and become more excited to speak out in class.

In teaching learning activities, students' perceptions give positive impact on the quality of interaction and quality communication. Widianingsih (2010) states that perception on learning deal with belief about knowledge which Influence students' approaches to learning. Tudor in (Kourieos and Evripidou, 2013) also stated that learners' perceptions about effective language learning seem to consciously or unconsciously which support their own learning and most importantly influence their positive reaction or resistance and discontent to teaching activities.

Therefore, an identification of students' perceptions is believed to bring the improvements that might help create a positive and academically productive in teaching learning process. In line with recent research, the aim of the study is to find out student's perception on the use of cooperative learning of Teknik Instrumentasi Elektronika Migas department of STT-Migas Balikpapan which can to the improvement for teaching and learning process. 


\section{METHOD}

This study used qualitative research which investigated the issue related to the student's perception on the use of cooperative learning which has been implemented for one semester. The students were assigned to work in group in every classroom activity.

Instrument in this research used questionnaire to collect the data which consisted of 12 questions. A survey questionnaire was distributed among the participants in order to determine their perception about employing cooperative learning. In this study, the researcher wanted to gain numerical data to indicate students' perception on cooperative learning. The questionnaire used is adopted from Mcleish (2009) in (Farzaneh and Nejadansari, 2014) and had 12 items (See Appendix A). For the purpose of analyzing the gathered data, the respondents were allowed to rate each item on a scale of options which were numerically coded as 1 (strongly disagree); (disagree); 3(neutral); 4(agree); 5(strongly disagree). The participant for the study was 24 of Teknik Instrumentasi Elektronika Migas learners, 20 male and and 4 female.

\section{FINDING AND DISCUSSION}

In this section the process of data analysis and the results achieved are presented. As mentioned in previous section, the data collected for this study was gathered through the distribution of a questionnaire (See Appendix A) among 24 TIEM learners in STT-Migas Balikpapan. The questionnaire adopted from Mcleish (2009) in (Farzaneh and Nejadansari, 2014) which related of cooperative learning. The data would explain in paragraph based on the table below.

Table 1

\begin{tabular}{|l|l|l|l|l|l|}
\hline \multirow{2}{*}{\multicolumn{1}{c|}{ Statement }} & \multicolumn{4}{l|}{ Student's Response } \\
\cline { 2 - 6 } & $\begin{array}{l}(5) \\
\text { Strongly } \\
\text { Agree }\end{array}$ & $\begin{array}{l}\text { Agree } \\
\text { Af) }\end{array}$ & Neutral & Disagree & $\begin{array}{l}\text { Strongly } \\
\text { Disagree }\end{array}$ \\
\hline $\begin{array}{l}\text { I willingly participate in } \\
\text { cooperative learning }\end{array}$ & 11 & 12 & 1 & 0 & 0 \\
\hline
\end{tabular}


The table shows that eleven $(45,8 \%)$ students were strongly agree, twelve (50\%) students agreed and one (4\%) willingly participate in cooperative learning.

Table 2

\begin{tabular}{|l|l|l|l|l|l|}
\hline \multirow{2}{*}{\multicolumn{1}{|c|}{ Statement }} & \multicolumn{4}{|l|}{ Student's Response } \\
\cline { 2 - 6 } & $\begin{array}{l}\text { (5) } \\
\text { Strongly } \\
\text { Agree }\end{array}$ & $\begin{array}{l}\text { (4) } \\
\text { Agree }\end{array}$ & $\begin{array}{l}\text { (3) } \\
\text { Neutral }\end{array}$ & $\begin{array}{l}\text { (3) } \\
\text { Disagree }\end{array}$ & $\begin{array}{l}\text { Strongly } \\
\text { Disagree }\end{array}$ \\
\hline $\begin{array}{l}\text { When I work with other students I } \\
\text { achieve more than when I work } \\
\text { alone }\end{array}$ & 2 & 12 & 9 & 1 & $(1)$ \\
\hline
\end{tabular}

Based on the table two, two $(8,3 \%)$ students were strongly agreed that work with other students achieve more than work alone, twelve (50\%) students were agreed that work with other students achieve more than work alone, nine $(37,5 \%)$ students were neutral work with other students achieve more than work alone, and one (4\%) disagreed that work with other students achieve more than work alone.

Table 3

\begin{tabular}{|c|l|l|l|l|l|}
\hline \multirow{2}{*}{ Statement } & \multicolumn{4}{|l|}{ Student's Response } \\
\cline { 2 - 6 } & $\begin{array}{l}\text { (5) } \\
\text { Strongly } \\
\text { Agree }\end{array}$ & $\begin{array}{l}(4) \\
\text { Agree }\end{array}$ & $\begin{array}{l}\text { (3) } \\
\text { Neutral }\end{array}$ & $\begin{array}{l}\text { (3) } \\
\text { Disagree }\end{array}$ & $\begin{array}{l}\text { Strongly } \\
\text { Disagree }\end{array}$ \\
\hline $\begin{array}{l}\text { Cooperative learning can improve } \\
\text { my attitude towards work }\end{array}$ & 1 & 12 & 10 & 1 & 0 \\
\hline
\end{tabular}

Based on the table three, one (4\%) students were strongly agreed, twelve (50\%) students were agreed, $10(41 \%)$ students neutral and one (4\%) disagreed that cooperative learning can improve my attitude towards work. 
Table 4

\begin{tabular}{|c|l|l|l|l|l|}
\hline \multirow{2}{*}{ Statement } & \multicolumn{4}{|l|}{ Student's Response } \\
\cline { 2 - 7 } & $\begin{array}{l}(5) \\
\text { Strongly } \\
\text { Agree }\end{array}$ & $\begin{array}{l}(4) \\
\text { Agree }\end{array}$ & $\begin{array}{l}\text { Neutral } \\
\text { Nisagree }\end{array}$ & $\begin{array}{l}\text { Strongly } \\
\text { Disagree }\end{array}$ \\
\hline $\begin{array}{l}\text { Cooperative learning helps me to } \\
\text { socialize more }\end{array}$ & 2 & 17 & 5 & 0 & 0 \\
\hline
\end{tabular}

Based on the table fourth, two $(8,3 \%)$ students were strongly agreed that cooperative learning helps me to socialize more, seventeenth (70\%) students were agreed that cooperative learning helps me to socialize more, and five (20\%) students were neutral that cooperative learning helps me to socialize more.

Table 5

\begin{tabular}{|c|l|l|l|l|l|}
\hline \multirow{2}{*}{\multicolumn{1}{|c|}{ Statement }} & \multicolumn{4}{|l|}{ Student's Response } \\
\cline { 2 - 6 } & $\begin{array}{l}(5) \\
\text { Strongly } \\
\text { Agree }\end{array}$ & $\begin{array}{l}\text { (4) } \\
\text { Agree }\end{array}$ & $\begin{array}{l}\text { (3) } \\
\text { Neutral }\end{array}$ & $\begin{array}{l}\text { (3) } \\
\text { Disagree }\end{array}$ & $\begin{array}{l}\text { Strongly } \\
\text { Disagree }\end{array}$ \\
\hline $\begin{array}{l}\text { Cooperative learning enhances } \\
\text { good working relationship among } \\
\text { student }\end{array}$ & 0 & 21 & 3 & 0 & 0 \\
\hline
\end{tabular}

Based on the table five, twenty one (87.5\%) students were agreed and three $(12.5 \%)$ students were neutral with cooperative learning enhances good working relationship among students

Table 6

\begin{tabular}{|l|l|l|l|l|l|}
\hline \multirow{2}{*}{ Statement } & \multicolumn{4}{|l|}{ Student's Response } \\
\cline { 2 - 6 } & $(5)$ & $(4)$ & $(3)$ & $(3)$ & $(1)$ \\
& Strongly & Agree & Neutral & Disagree & Strongly \\
Agree & & & & Disagree \\
\hline
\end{tabular}




\begin{tabular}{|l|l|l|l|l|l|}
\hline $\begin{array}{l}\text { Cooperative learning enhances } \\
\text { class participation }\end{array}$ & 1 & 16 & 5 & 2 & 0 \\
\hline
\end{tabular}

Based on the table six, one (4\%) students were strongly agreed that cooperative learning enhances class participation, sixteenth (66.6\%) were agreed that cooperative learning enhances class participation, five (20.8\%) were neutral that cooperative learning enhances class participation, and two (8.3\%) were disagreed that cooperative learning enhances class participation.

Table 7

\begin{tabular}{|l|l|l|l|l|l|}
\hline \multirow{2}{*}{ Statement } & \multicolumn{4}{|l|}{ Student's Response } \\
\cline { 2 - 6 } & $\begin{array}{l}\text { (5) } \\
\text { Strongly } \\
\text { Agree }\end{array}$ & $\begin{array}{l}(4) \\
\text { Agree }\end{array}$ & $\begin{array}{l}\text { (3) } \\
\text { Neutral }\end{array}$ & $\begin{array}{l}\text { (3) } \\
\text { Disagree }\end{array}$ & $\begin{array}{l}\text { Strongly } \\
\text { Disagree }\end{array}$ \\
\hline $\begin{array}{l}\text { Creativity is facilitated in the } \\
\text { group setting }\end{array}$ & 2 & 8 & 12 & 2 & 0 \\
\hline
\end{tabular}

Based on the table seventh, two (8.3\%) students were strongly agreed, eight (33.3\%) students were agreed, twelve (50\%) students were neutral and two (8.3\%) were disagreed that creativity is facilitated in the group setting.

Table 8

\begin{tabular}{|c|l|l|l|l|l|}
\hline \multirow{2}{*}{ Statement } & \multicolumn{4}{|l|}{ Student's Response } \\
\cline { 2 - 7 } & $\begin{array}{l}\text { (5) } \\
\text { Strongly } \\
\text { Agree }\end{array}$ & $\begin{array}{l}\text { (4) } \\
\text { Agree }\end{array}$ & $\begin{array}{l}\text { (3) } \\
\text { Neutral }\end{array}$ & $\begin{array}{l}\text { (3) } \\
\text { Disagree }\end{array}$ & $\begin{array}{l}\text { (1) } \\
\text { Strongly } \\
\text { Disagree }\end{array}$ \\
\hline $\begin{array}{l}\text { Group activities make the learning } \\
\text { experience easier }\end{array}$ & 7 & 13 & 4 & 0 & 0 \\
\hline
\end{tabular}

Based on the table eight, seventh (29\%) students were strongly agreed that group activities make the learning experience easier, thirteenth (54.1\%) students were agreed that group activities make the learning experience easier and fourth (16.6\%) students were neutral group activities make the learning experience easier. 
Table 9

\begin{tabular}{|l|l|l|l|l|l|}
\hline \multirow{2}{*}{ Statement } & \multicolumn{4}{l|}{ Student's Response } \\
\cline { 2 - 6 } & $\begin{array}{l}\text { (5) } \\
\text { Strongly } \\
\text { Agree }\end{array}$ & $\begin{array}{l}\text { Agree } \\
\text { Af) }\end{array}$ & $\begin{array}{l}\text { Neutral } \\
\text { Disagree }\end{array}$ & $\begin{array}{l}\text { Strongly } \\
\text { Disagree }\end{array}$ \\
\hline $\begin{array}{l}\text { I learn to work with students who } \\
\text { are different from me }\end{array}$ & 6 & 10 & 8 & 0 & 0 \\
\hline
\end{tabular}

Based on the table nine, six (25\%) students were strongly agreed, tenth (41.6\%) students were agreed and eight (33.3\%) students were neutral that work with students who are different from them.

Table 10

\begin{tabular}{|l|l|l|l|l|l|}
\hline \multirow{2}{*}{ Statement } & \multicolumn{4}{l|}{ Student's Response } \\
\cline { 2 - 6 } & $\begin{array}{l}(5) \\
\text { Strongly } \\
\text { Agree }\end{array}$ & $\begin{array}{l}\text { Agree } \\
\text { Ag) }\end{array}$ & $\begin{array}{l}\text { Neutral } \\
\text { Aisagree }\end{array}$ & $\begin{array}{l}\text { Strongly } \\
\text { Disagree }\end{array}$ \\
\hline $\begin{array}{l}\text { I enjoy the material more when I } \\
\text { work with other students }\end{array}$ & 2 & 8 & 13 & 0 & 0 \\
\hline
\end{tabular}

Based on the table tenth, two (8.3\%) students were strongly agreed that they enjoy the material more when work other students, eight (33.3\%) students were agreed that they enjoy the material more when work other students, and thirteen (54.1\%) students were neutral that they enjoy the material more when work other students. 
Table 11

\begin{tabular}{|c|l|l|l|l|l|}
\hline \multirow{2}{*}{ Statement } & \multicolumn{4}{|l|}{ Student's Response } \\
\cline { 2 - 6 } & $\begin{array}{l}\text { (5) } \\
\text { Strongly } \\
\text { Agree }\end{array}$ & $\begin{array}{l}(4) \\
\text { Agree }\end{array}$ & $\begin{array}{l}\text { (3) } \\
\text { Neutral }\end{array}$ & $\begin{array}{l}\text { (3) } \\
\text { Disagree }\end{array}$ & $\begin{array}{l}\text { (1) } \\
\text { Strongly } \\
\text { Disagree }\end{array}$ \\
\hline $\begin{array}{l}\text { My work is better organized when } \\
\text { I am in group }\end{array}$ & 2 & 13 & 9 & 0 & 0 \\
\hline
\end{tabular}

Based on the table eleventh, two (8.3\%) students were strongly agreed, thirteen (54.1\%) students were agreed and nine (37.5\%) students were neutral that their work is better organized when they in work in group.

Table 12

\begin{tabular}{|c|c|c|c|c|c|}
\hline \multirow[b]{2}{*}{ Statement } & \multicolumn{5}{|c|}{ Student's Response } \\
\hline & $\begin{array}{l}5) \\
\text { Strongly } \\
\text { Agree }\end{array}$ & \begin{tabular}{|l}
$(4)$ \\
Agree
\end{tabular} & $\begin{array}{l}\text { (3) } \\
\text { Neutral }\end{array}$ & $\begin{array}{l}(3) \\
\text { Disagree }\end{array}$ & $\begin{array}{l}(1) \\
\text { Strongly } \\
\text { Disagree }\end{array}$ \\
\hline $\begin{array}{l}\text { I prefer that my teachers use more } \\
\text { group activities }\end{array}$ & & 16 & 8 & 0 & 0 \\
\hline
\end{tabular}

Based on the table twelve, sixteenth (66.6\%) students were agreed and eight (33.5\%) students were neutral that prefer their teacher use more group activities.

From students 'perception of applying cooperative learning in students of TIEM above, cooperative enhances good working relationship among students mostly agreed by EFL learners $(87,5 \%)$, and then it was (70\%) learners agreed by cooperative learning help to socialize more and the last which percentage of $(66,6 \%)$ they agreed with cooperative learning enhances class participation.

This discussion is derived from the data analysis that explained in the previous section. Based on the findings, the results of this study showed that the three statements agreed with the most were chosen by students are items 4, 5 and 6 . Most of students feel confidents when they work in group, it helps raise their achievement, build positive relationships among students, and 
also provide experiences that develop both good learning skills and social skills in teaching learning activities. As supported by (Al-yaseen, 2014) stated that cooperative learning has positive effects on student achievement, increases student relationships and increases self-esteem, the benefits of cooperative learning help EFL learners improve efficiency in their language learning.

\section{CONCLUSION}

This result of this study indicate that the participant generally showed a positive view on the implementation of cooperative strategies in teaching and learning context. This is probably because when students work in groups they feel that they can depend on other for help and this gives them confidence to solve problems and enjoy learning.

At the end, finding of this study shows cooperative learning experiences contribute to social skills growth, where positive interpersonal and social relationship became noticeable and more diverse. Through cooperative learning, individual and group work skills development enhance students' achievement. This is in line with the improvement in students' behavior and their interpersonal relationships. This finding agrees with Miller, K.L (2017) that cooperative learning groups encourages students involvement with each other, helping each other's learning and developing social behaviors that encourage groups' active participation.

However, the benefits of cooperative learning are not automatically earned. It will create considerable difficulties to the lecturers, dysfunctional teams and student resistance or resentment to group work if it is not appropriately implemented.

\section{REFERENCES}

Al-yaseen, W. S. (2014) 'Cooperative Learning in the EFL Classroom’, pp. 92-98.

Farzaneh, N. and Nejadansari, D. (2014) 'Students' attitude towards using cooperative learning for teaching reading comprehension', Theory and Practice in Language Studies. doi: 10.4304/tpls.4.2.287-292.

Hidayati, L. A., Kharisma, I. and Satriani, I. (2018) 'STUDENTS’ PERCEPTION IN APPLYING COOPERATIVE LEARNING IN EFL CLASSROOM', ETERNAL (English, Teaching, Learning and Research Journal). doi: 10.24252/eternal.v41.2018.a2.

Jacobs, G. M. and McCafferty, S. G. . (2006) 'Connections between cooperative learning and second language learning and teaching', Cooperative learning and second language teaching. 
Kourieos, S. and Evripidou, D. (2013) 'Students' Perceptions of Effective EFL Teachers in

University Settings in Cyprus', 6(11). doi: 10.5539/elt.v6n11p1.

Miller, K. L. (2017) 'BUILDING A CULTURE OF EFFECTIVE COOPERATIVE

LEARNING : TEACHER by'.

\section{Appendix A}

Dear respondent,

This questionnaire is designed to investigate students' perception on the use of cooperative learning. The research really appreciates your cooperation and participation, to respond to this questionnaire, please put a check mark $(\checkmark)$ in the appropriate box to indicate your level of agreement or disagreement with the statements: 1 (strongly disagree); 2 (disagree); 3 (neutral); 4 (agree); and 5 (strongly agree).

\begin{tabular}{|c|c|c|c|c|c|c|}
\hline No & Statement & 1 & 2 & 3 & 4 & 5 \\
\hline $\mathbf{1}$ & I willingly participate in cooperative learning & & & & & \\
\hline 2 & $\begin{array}{l}\text { When I work with other students I achieve } \\
\text { more than when I work alone }\end{array}$ & & & & & \\
\hline 3 & $\begin{array}{l}\text { Cooperative learning can improve my attitude } \\
\text { towards work }\end{array}$ & & & & & \\
\hline 4 & $\begin{array}{l}\text { Cooperative learning helps me to socialize } \\
\text { more }\end{array}$ & & & & & \\
\hline 5 & $\begin{array}{l}\text { Cooperative enhances good working } \\
\text { relationship among students }\end{array}$ & & & & & \\
\hline 6 & $\begin{array}{|lll|}\text { Cooperative learning enhances class } \\
\text { participation }\end{array}$ & & & & & \\
\hline 7 & Creativity is facilitated in the group setting & & & & & \\
\hline 8 & $\begin{array}{l}\text { Group activities make the learning experience } \\
\text { easier }\end{array}$ & & & & & \\
\hline 9 & $\begin{array}{l}\text { I learn to work with students who are different } \\
\text { from me }\end{array}$ & & & & & \\
\hline
\end{tabular}




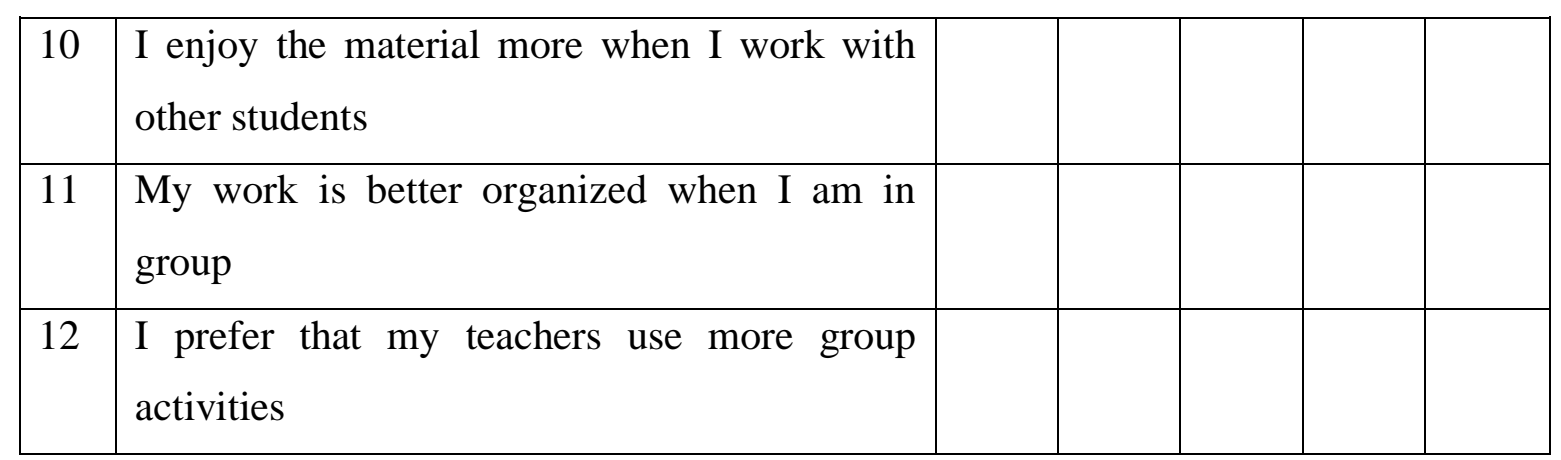

